\title{
Pattern of Maxillofacial fracture in Western and Central Nepal: An experience in 3 tertiary level health institutions
}

\author{
Subedi $S^{1}$, Shrestha $B^{2}$, Adhikari RB ${ }^{3}$ \\ ${ }^{1}$ Assistant Professor, Dept of Oral and Maxillofacial Surgery, Chitwan Medical College, ${ }^{2}$ Assistant Professor, \\ Dept of Oral Pathology, Chitwan Medical College, ${ }^{3}$ Assistant Professor, Department of Dentistry, Manipal \\ Medical College and teaching hospital, Pokhara
}

\section{ABSTRACT}

Background: There are only few studies regarding the pattern and causes of maxillofacial fractures till date in Nepal and no such study in western and central Nepalese population has been conducted. The purpose of this study, therefore, was to describe the causes and the pattern of maxillofacial fractures in western and central part of Nepal over the period of 5 years.

\section{MATERIALAND METHODS}

A retrospective analysis of maxillofacial fractures was conducted on 328 patients who were treated in the department of maxillofacial surgery. Data was extracted and analyzed based on age, sex, cause of injury and anatomic location.

\section{RESULT}

Young males of 3rd decade of life most commonly sustained the maxillofacial trauma. The commonest site involved was the zygomatic complex (42\%) when only mid face fractures was considered and parasymphysis (32\%) when only mandible was considered.The most common cause of injuries was road traffic accidents (289 patients; $88.1 \%$ ) followed by interpersonal violence (25 patients; $7.6 \%$ ) and falls accounting for $4.2 \%$ of the all injuries.

\section{CONCLUSION}

The findings of this study suggest the need for expansion of the motorway network, ensuring compliance of strict traffic rules and regulations, replacing old vehicles without safety measures and implement school education in alcohol abuse. 


\section{INTRODUCTION}

The maxillofacial region is the most exposed part of the body and is vulnerable to traumatic injuries. ${ }^{1}$ In developing countries, road traffic accidents have been reported as the main cause of maxillofacial injuries whereas interpersonal violence as the main cause in developed countries. ${ }^{2,3}$ The causes of maxillofacial injuries vary widely from one country to another and even within same country depending upon social, cultural, and environmental factors. ${ }^{1,4}$

An understanding of the cause and distribution of maxillofacial injuries can help in establishing priorities for effective treatment and allows the development and evaluation of preventative measures. ${ }^{5}$

Studies regarding the pattern and cause of maxillofacial injuries have been conducted in developing as well as developed country. There are only few related studies till date in developing country, Nepal and no such study in western and central Nepalese population has been conducted. The purpose of this study, therefore, was to describe the causes and the pattern of maxillofacial fractures in western and central part of Nepal over the period of 5 years. The purpose of this study, therefore, was to describe the causes of maxillofacial fractures, the distribution of these fractures among maxillofacial bones, and the distribution among different age groups and between the sexes seen in western and central part of Nepal over the period of 5 years. The aim was to generate information that can be used for the development of public health programs for education and prevention.

\section{MATERIALS AND METHOD}

All the cases of maxillofacial fractures treated in the department of maxillofacial surgery from January 2010 to December 2014 in three tertiary level health institutions- Chitwan Medical College and hospital, Bharatpur, Gandaki Medical College and hospital and Manipal Medical College and hospital, Pokhara were included in the study. The data underwent retrospective analysis for age, gender specificity, etiology, and sites of fracture. SPSS version 16 was used to analyse the data.

\section{RESULT}

A total of 328 patients sustaining maxillofacial fractures were treated between January 2010 and December 2014. There were 267 males (81.4\%) and 61 females $(18.6 \%)$ (as shown in Figure 1), giving a male to female ratio of $4: 1$. Most of the patients $(121 ; 36.9 \%)$ were in the age group of 20-29 years, while the smallest number of patients $(2 ; 0.7 \%)$ was over the age of 70 (as shown in Table 1). The most common cause of injuries was road traffic accidents (289 patients; $88.1 \%$ ) followed by interpersonal violence $(25 ; 7.6$ $\%$ ) and falls (14; 4.2\%) (as shown in Table 2). A total of 166 cases sustained the Mandibular fractures. The distribution of the Mandibular fractures by site is shown in Table 3. The most common site was the parasymphysis of the mandible (53 cases; $32 \%$ of Mandibular fractures), followed by the symphysis ( 30 ; $18 \%)$, the body $(20 ; 12 \%)$, the condyle $(13 ; 7.8 \%)$ and angle $(9 ; 5.4 \%)$. A considerable proportion of the patients $(40 ; 24 \%)$ had involvement of more than one site of mandibular fracture.

The distribution of maxillary fractures by site is shown in Table 4 which shows 159 cases sustained maxillary fracture. The most common site was zygomatic complex (ZMC) seen in 67 (42\%) followed by nasal complex $(25 ; 15.7 \%)$, and dentoalveolar fractures $(14$; 
8.8\%). A few number of patient had involvement of more than one site of mid face fractures (19 cases ; $12 \%)$.

Out of the total of 238 patients, 9 cases $(3.8 \%)$ presented with involvement of both the mid face and the mandibular fractures and panfacial fractures were treated in $3(1.3 \%)$ patients as shown in Table 5.

Figure 1. Pie chart showing percentage of gender distribution of maxillofacial fracture

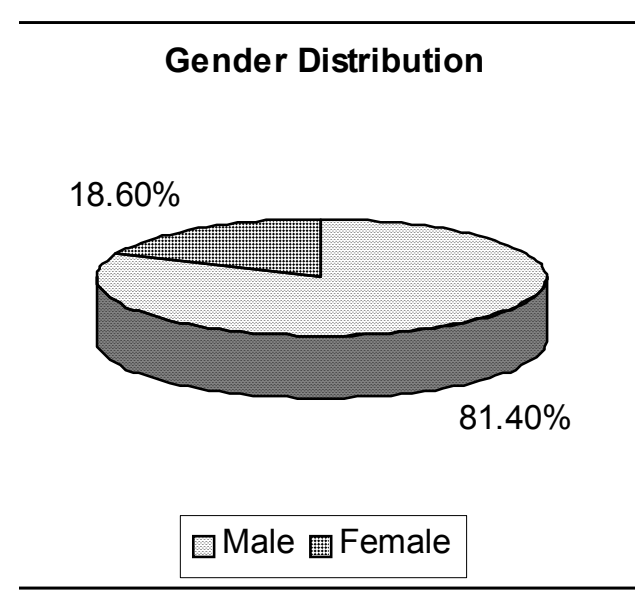

Table 1 showing age distribution of the cases sustaining the maxillofacial fracture

\begin{tabular}{lcc}
$\begin{array}{l}\text { Age Distribution } \\
\text { in years }\end{array}$ & $\begin{array}{c}\text { Number } \\
\text { of cases }\end{array}$ & Percentage \\
\hline $\mathbf{0 - 9}$ & 18 & 5.5 \\
$\mathbf{1 0 - 1 9}$ & 47 & 14.3 \\
$\mathbf{2 0 - 2 9}$ & 121 & 36.9 \\
$\mathbf{3 0 - 3 9}$ & 75 & 22.9 \\
$\mathbf{4 0 - 4 9}$ & 36 & 11 \\
$\mathbf{5 0 - 5 9}$ & 18 & 5.5 \\
$\mathbf{6 0 - 6 9}$ & 11 & 3.3 \\
$\mathbf{7 0 - 7 9}$ & 1 & 0.3 \\
$\mathbf{8 0 - 8 9}$ & 1 & 0.3 \\
\end{tabular}

Table 2 showing the Etiology of Maxillofacial Fractures

\begin{tabular}{lcc|} 
Etiology & $\begin{array}{c}\text { Number } \\
\text { of cases }\end{array}$ & Percentage \\
\hline Road Traffic accidents & 289 & 88 \\
Interpersonal Violences & 25 & 7.6 \\
Fall & 14 & 4.2 \\
\hline
\end{tabular}

Table 3 showing anatomical distribution of Mandibular Fracture

\begin{tabular}{|c|c|c|}
\hline $\begin{array}{l}\text { Anatomical distribution } \\
\text { of Mandibular } \\
\text { Fractures }\end{array}$ & $\begin{array}{l}\text { Number } \\
\text { of Cases }\end{array}$ & Percentage \\
\hline Symphysis & 30 & 18 \\
\hline Parasymphysis & 53 & 32 \\
\hline Body & 20 & 12 \\
\hline Angle & 9 & 5.4 \\
\hline Ramus & 1 & 0.6 \\
\hline $\begin{array}{l}\text { Condyle(Condylar Head/ } \\
\text { Sub Condyle) }\end{array}$ & 13 & 7.8 \\
\hline Symphysis + Parasymphysis & 3 & 1.8 \\
\hline Parasymphysis + Angle & 7 & 4.2 \\
\hline Body + Condyle & 5 & 3 \\
\hline Condyle + Angle & 2 & 1 \\
\hline Symphysis + Condyle & 11 & 6.6 \\
\hline Parasymphysis + Condyle & 5 & 3 \\
\hline Body + Angle & 3 & 1 \\
\hline Symphysis + Body + Angle & 2 & 1.2 \\
\hline Symphysis + Angle & 2 & 1.2 \\
\hline
\end{tabular}


Table 4 showing anatomical distribution of Mid facial Fracture

\begin{tabular}{|c|c|c|}
\hline $\begin{array}{l}\text { Anatomical Distribution } \\
\text { of Mid } \\
\text { Facial Fracture }\end{array}$ & $\begin{array}{c}\text { Number } \\
\text { of } \\
\text { Cases }\end{array}$ & Percentage \\
\hline Lefort I & 11 & 7 \\
\hline Lefort II & 7 & 4.4 \\
\hline Lefort III + Palatal Split & 1 & 0.6 \\
\hline Zygomatic complex (ZMC) & 67 & 42 \\
\hline Zygomatic arch & 10 & 6.3 \\
\hline Nasal Complex & 25 & 15.7 \\
\hline Dentoalvelar & 14 & 8.8 \\
\hline Orbital & 5 & 3 \\
\hline Palatal Split + Orbital & 1 & 0.6 \\
\hline \multicolumn{3}{|l|}{ Lefort I + Palatal Split + } \\
\hline Dentoalveolar & 1 & 0.6 \\
\hline Lefort I + Orbital & 1 & 0.6 \\
\hline ZMC + Orbital & 3 & 1.8 \\
\hline Lefort I + ZMC & 9 & 5.6 \\
\hline Lefort I +arch & 1 & 0.6 \\
\hline Lefort II +ZMC & 3 & 1.8 \\
\hline
\end{tabular}

Table 5 showing anatomical distribution of combination of Mandibular and mid face fracture

\begin{tabular}{|c|c|c|}
\hline Anatomical Distribution & Number & \\
\hline of MandibularAnd Mid & of & Percentage \\
\hline Face Fracture & Cases & \\
\hline Lefort I + Body & 1 & 0.3 \\
\hline Zygomatic complex (Z & + Angle & 10.3 \\
\hline
\end{tabular}

Lefort II + Symphysis + Parasymphysis 10.3

Lefort I + Parasymphysis $\quad 1 \quad 0.3$

Parasymphysis + Condyle + Orbital 10.3

Symphysis + Nasal Bone $\quad 1 \quad 0.3$

$\begin{array}{lll}\text { ZMC + Condyle } & 1 & 0.3\end{array}$

$\begin{array}{lll}\text { ZMC+Body } & 1 & 0.3\end{array}$

$\begin{array}{lll}\text { Parasymphysis }+\mathbf{Z M C} & 1 & 0.3\end{array}$

$\begin{array}{lll}\text { Panfacial } & 3 & 0.9\end{array}$ 


\section{DISCUSSION}

Remarkable regional variations in the incidence, etiology, and site distribution of maxillofacial fractures depending upon the geographic conditions, cultural characteristics, road safety regulations, alcohol abuse and socioeconomic trends is observed. ${ }^{6}$ The predominance of male and occurrence in the age group 20-29-year-old are the consistent findings. In this study the male to female ratio is $4: 1$ which is similar to study by Fasola et al, ${ }^{7}$ Subhashraj K et $a 1^{8}$ and the western population ${ }^{3}$. This trend is observed because males are more involved in outdoor activities and are also exposed to violent interactions as compared to females who are less exposed due to social and religious limitations. ${ }^{7}$ Male vehicle drivers also far outnumber females.

In Western and Indian population, $3^{\text {rd }}$ decade of life seems to have the highest incidence of facial fractures. ${ }^{3,8}$ The high incidence in 3rd decade of life might be due to the facts that people belonging to this decade are more active, energetic, are involved in many outdoor activities, reckless driving, take active participation in dangerous exercises and sports activities and mostly involved in violence..$^{7-10}$ This finding is supported by our study in which more than $80 \%$ of the study populations were males and majority were in the age range of 20-29years.

In this study, an incidence of $4 \%$ maxillofacial fractures was noted for older age group ( $>60$ years). This finding is supported by the fact that this age group is less active and less involved in outdoor activities. Activities of daily life accidents dominated in elderly people from the sixth to the tenth decade. ${ }^{11}$
Road traffic accidents (RTA) are still the main cause of maxillofacial trauma in developing countries, ranging from 55.2 to $91 \%{ }^{3,12}$ In this study, $88 \%$ maxillofacial fractures were caused by road traffic accidents followed by interpersonal violence $(7.6 \%)$ and fall $(4.2 \%)$. The reasons for higher frequency of RTA in these regions can be attributed to poor road conditions, underage driving, inadequate road safety awareness, old vehicles without safety features, over- speeding, over-loading, lack of strict seat belt law obligation and substance abuse. ${ }^{8,9,13}$ Conversely in Western society, there is a downward trend in the incidence of RTArelated facial fractures, and interpersonal violence has become the leading cause. ${ }^{3}$

Fracture of mandible is the most common fracture of facial bone according to the existing literature. In contrast, we found equal incidence of Mandibular and mid face fracture. In the present series, among the mandibular fracture sites, parasymphysis (32\%) was the most common fracture site followed by the symphysis (18\%). A considerable proportion of the patients $(40 ; 24 \%$ ) had involvement of more than one site of mandibular fracture. The site of fracture probably reflects the direction from which force was applied to the mandible. ${ }^{14}$

In our study, in middle third fractures, Zygomatic complex (42\%) was most commonly involved followed by nasal complex $(25 ; 15.7 \%)$. This is because zygomatic bone and nasal bone are prominent part which is more vulnerable to trauma. ${ }^{15}$ In this study, maxillofacial fracture involved both the mid face and the Mandibular fracture in $4 \%$ of patients and $0.3 \%$ showed panfacial fractures. 


\section{CONCLUSION}

In this retrospective study of 328 cases of maxillofacial fractures in Central and Western Nepalese population over a period of five years, road traffic accident was the most common cause of maxillofacial fracture. Most fractures occurred in the age range of 20-29 years.

Public health programs for education and prevention should be aimed at reducing the incidence of maxillofacial fractures. Preventive strategies remain the cheapest way to reduce direct and indirect costs of the management of trauma.

This can be done by expansion of the motorway network with wider roads, ensuring strict compliance of traffic rules and regulations, replacing old vehicles without safety measures and implement school education in alcohol abuse. Significant reduction in the incidence of maxillofacial fractures will be seen only when attitudes and behaviors of society is modified.

\section{REFERENCES}

1. Olasoji HO, Tahir A, Arotiba GT. Changing picture of facial fractures in northern Nigeria. Br J Oral Maxillofac Surg 2002;40:140-3.

2. Oji C. Jaw fractures in Enugu, Nigeria, 1985-95. Br J Oral Maxillofac Surg 1999;37:106-9.

3. $\mathrm{K}$ Lee. Global trends in maxillofacial fractures. Craniomaxillofac Trauma Reconstr 2012;5:213-22.

4. Bataineh AB. Etiology and incidence of maxillofacial fractures in the north of Jordan. Oral Surg Oral Med Oral Pathol Oral Radiol Endod 1998;86:31-5.

5. Gassner R, Tuli T, Hächl O, et al. Cranio-maxillofacial trauma: a 10 year review of 9,543 cases with 21,067 injuries. J Craniomaxillofac Surg 2003;3:51-61.
6. Ascani G, Di Cosimo F, Costa M, et al.Maxillofacial fractures in the province of Pescara, Italy: a retrospective study. ISRN Otolaryngol 2014 Jan 23;2014:101370. doi: 10.1155/2014/101370.

7. Fasola AO, Nyako EA, Obiechina AE, et al. Trends in the characteristics of maxillofacial fractures in Nigeria. J Oral Maxillofac Surg 2003;61:1140-3.

8. Subhashraj K, Nandakumar N, Ravindran C. Review of maxillofacial injuries in Chennai, India: a study of 2748 cases. Br J Oral Maxillofac Surg 2007;45:637-9.

9. Udeabor SE, Akinbami BO, Yarhere KS, et al. Maxillofacial Fractures: Etiology, Pattern of Presentation, and Treatment in University of Port Harcourt Teaching Hospital, Port Harcourt, Nigeria, Journal of Dental Surgery; vol. 2014, Article ID 850814, 5 pages, 2014. doi:10.1155/2014/850814

10. Brasileiro BF, Passeri LA. Epidemiological analysis of maxillofacial fractures in Brazil: a 5-year prospective study. Oral Surg Oral Med Oral Pathol Oral Radiol Endod 2006;102:28-34.

11. Gassner R, Tuli T, Hächl O, et al. Craniomaxillofacial trauma: a 10 year review of 9,543 cases with 21,067 injuries. J Craniomaxillofac Surg 2003;3:5161.

12. Alves LS, Aragão I, Sousa MJ, et al. Pattern of maxillofacial fractures in severe multiple trauma patients: a 7-year prospective study. Braz Dent J 2014;25:561-4.

13. Ansari MH. Maxillofacial fractures in Hamedan province, Iran: a retrospective study (1987-2001). J Craniomaxillofac Surg 2004;32:28-34.

14. King RE, Scianna JM, Petruzzelli GJ. Mandible fracture patterns: a suburban trauma centre experience. Am J Otolaryngol 2004;25:301-07.

15. Covington DS, Wainwright DJ, Teichgraeber JF, et al. Changing patterns in the epidemiology and treatment of zygoma fractures: 10-year review. J Trauma 1994;37:243-8. 